\title{
Rencontre avec Dominique Pitoiset
}

\section{(2) OpenEdition}

1 Journals

\section{Édition électronique}

URL : http://journals.openedition.org/shakespeare/1265

DOI : 10.4000/shakespeare.1265

ISSN : 2271-6424

Éditeur

Société Française Shakespeare

\section{Édition imprimée}

Date de publication : 1 novembre 1993

Pagination : 173-175

\section{Référence électronique}

"Rencontre avec Dominique Pitoiset 》, Actes des congrès de la Société française Shakespeare [En ligne], 11 | 1993, mis en ligne le 01 janvier 2007, consulté le 19 avril 2019. URL : http://

journals.openedition.org/shakespeare/1265; DOI : 10.4000/shakespeare.1265

Ce document a été généré automatiquement le 19 avril 2019.

(c) SFS 


\section{Rencontre avec Dominique Pitoiset}

